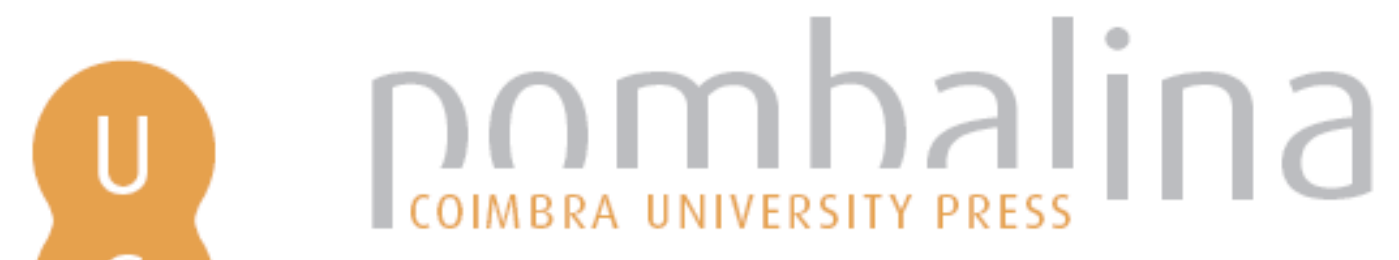

\title{
Dimensionality of Career Indecision: Methodological Perspectives
}

\author{
Autor(es): Shimizu, Kazuaki
}

Publicado por: Imprensa da Universidade de Coimbra

URL

persistente: URI:http://hdl.handle.net/10316.2/43654

DOI: $\quad$ DOl:https://doi.org/10.14195/978-989-26-1451-9_7

Accessed : $\quad$ 26-Apr-2023 12:22:55

A navegação consulta e descarregamento dos títulos inseridos nas Bibliotecas Digitais UC Digitalis, UC Pombalina e UC Impactum, pressupõem a aceitação plena e sem reservas dos Termos e Condições de Uso destas Bibliotecas Digitais, disponíveis em https://digitalis.uc.pt/pt-pt/termos.

Conforme exposto nos referidos Termos e Condições de Uso, o descarregamento de títulos de acesso restrito requer uma licença válida de autorização devendo o utilizador aceder ao(s) documento(s) a partir de um endereço de IP da instituição detentora da supramencionada licença.

Ao utilizador é apenas permitido o descarregamento para uso pessoal, pelo que o emprego do(s) título(s) descarregado(s) para outro fim, designadamente comercial, carece de autorização do respetivo autor ou editor da obra.

Na medida em que todas as obras da UC Digitalis se encontram protegidas pelo Código do Direito de Autor e Direitos Conexos e demais legislação aplicável, toda a cópia, parcial ou total, deste documento, nos casos em que é legalmente admitida, deverá conter ou fazer-se acompanhar por este aviso.

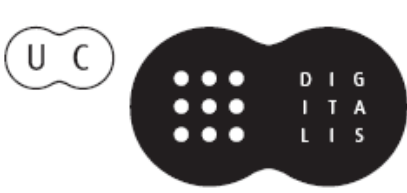


JOAQUIM ARMANDO FERREIRA MATTHIAS REITZLE

EDUARDO SANTOS (EDS.)

\section{CAREER \\ DEVELOPMENT \\ IN CONTEXT}

FESTSCHRIFT FOR

FRED VONDRACEK 


\title{
V I I
}

\section{DIMENSIONALITY OF CAREER INDECISION : METHODOLOGICAL PERSPECTIVES}

\author{
Kazuaki Shimizu, Kansai University, \\ Japan; shimizu@kansai-u.ac.jp \\ https://doi.org/10.14195/978-989-26-1451-9_7
}

\begin{abstract}
The dimensionality of career indecision has been the subject of theorizing and empirical research for more than seventy years. Many studies, however, have methodological shortcomings that preclude the necessary distinction between career indecision and career indecisiveness. One possible solution to the problem would be to employ recent methodological advances to identify latent trait and latent state dimensions in items designed to examine career indecision and indecisiveness. More definitive findings regarding the career indecisiveness-indecision distinction will require what Vondracek and his colleagues suggested more than thirty years ago: longitudinal research designs using state of the art analytical methods.
\end{abstract}

Keywords: career indecision, career indecisiveness, longitudinal research designs. 


\section{Introduction}

Over the past 70 years a large body of research has been accumulated on the multidimensionality of career indecision. Disparate findings have fueled ongoing discussions among researchers and practitioners in the fields of vocational/career counseling and career development. Although the most common contents of constructed scales for career indecision are consistent with vocational/career counseling observations by pioneers in this field, there are some remaining issues regarding the distinction between career indecision and career indecisiveness. In this chapter, inspired by the writings of $\mathrm{E}$. G. Williamson (1939), I will review selected scales developed for measuring career indecision. In order to shed new light upon the relationships between career indecision and career indecisiveness, current methodologies designed to examine the trait-state distinction in human development are introduced.

\section{Diagnostic approach for vocational problems}

Williamson (1939) defined the four key problems of vocational choice as uncertain vocational choice, no vocational choice, discrepancy between interests and aptitudes, and unwise vocational choice. He also discussed the role of vocational indecision in causing vocational choice uncertainty and in the failure to make a vocational choice. For example, he said "The causes of vocational choice uncertainty are many, usually consisting of fear and lack of aptitude, fear of displeasing parents and friends, and fear of failure in chosen occupations" (p.414), and "many students are unable to decide definitely even though there are several occupations which appeal to them" (pp.431-432). Bordin 
(1946) reconsidered these problems with reference to the psychodynamic position of vocational counseling and proposed the new diagnostic categories for the classification of vocational problems as self-conflict, lack of information, dependence, choice anxiety, and no problem (see also Byrne, 1958; Pepinsky, 1948, and Robinson, 1950, 1963). More than two decades after his original classification, Bordin (1968) reclassified these problems into dependence, lack of information, self-conflict, choice anxiety, and lack of assurance (Bordin \& Kopplin, 1973).

Criticizing the unreliability of approaches such as Bordin's, Crites (1969) proposed that vocational problems should be conceptualized as problems of adjustment, problems of indecision, and problems of unrealism. He further proposed an integrated system of classification criteria for career choice problems based on the trait-factor approach (see also Crites, 1981). After reviewing various classifications of vocational/career choice problems, Rounds and Tinsley (1984) raised concerns that "the heuristic value of the classification system may be compromised by tautology" (p.154). Spokane (1991) also pointed out that such problem diagnoses "while intellectually rich, have not led to research and evaluation, since the link between the categories and existing diagnostic measures and possible interventions is not clear" (p.77).

\section{Typological approaches for studying career indecision}

Career counseling for students might start with the question "what is your career choice?" Based on their answers to this, they would be classified into two groups; a decided group and an undecided group. After investigating the characteristics of decided versus undecided students, Williamson (1939) concluded that there were no differences in academic aptitude and so- 
cio-economic status, findings that were also reported by others (e.g., Baird, 1968, 1969; Slaney, 1980). Decided and undecided students differed, however, on scales specifically constructed to measure career indecision (Slaney, 1980).

The most important one of such scales for measuring career indecision in vocational/career counseling and research has been the Career Decision Scale (CDS: Osipow, Carney, \& Barak, 1976). Osipow and his colleagues developed the CDS "to standardize the identification of sources of career indecision to serve as a diagnostic aid in using a series of structured interventions" (Osipow, 1991, p.232).

Two different directions of research were inspired by the CDS. One was designed to create a typology of career indecision based on the tradition of diagnostic categories for vocational problems in career counseling. Accordingly, Savickas and Jarjoura (1991) used cluster analysis procedures to identify career indecision types using the items of the CDS. Other cluster analytic studies of career decision status were conducted with various psychological scales related to indecision and to decision making. For example, Larson, Heppner, Ham, and Dugan (1988) reported four clusters such as planless avoider, informed indecisives, confident but uninformed, and uninformed in response to the CDS, the CPI (Career Planning Inventory), the PSI (Problem Solving Inventory: Heppner \& Petersen, 1982), and the Consistency and Differentiation of the VPI (Vocational Preference Inventory: Holland, 1978). Wanberg and Muchinsky (1992) reported also four clusters such as confident decided individuals, concerned decided individuals, indifferent undecided individuals, and anxious undecided individuals using the CDS, the Career Decision Profile (CDQ: Jones, 1989), the MVS (My Vocational Situation: Holland, Daiger, \& Power, 1980), and personality measures including state and trait anxiety. Based on theoretical considerations, Gati, Krausz, 
and Osipow (1996) proposed a typology of ten career decision making difficulties and developed the Career Decision-Making Difficulties Questionnaire (CDDQ).

Traditionally, researchers in the field of counseling often classify clients into various types depending on their diagnostic purposes. Although cluster analysis is suitable for identifying groups of observed variables under investigation, groups discovered by this method vary with the calculation methods that are used (e.g., distance among variables; algorithms used to calculate clusters; variables included for calculation). Moreover, the advantage of calculating for the best cluster for the focus group of a given study might be one of the disadvantages in cross-group studies. In other words, cluster analysis is not suitable for establishing or confirming the invariance of measurement among culturally or developmentally different groups. Researchers using this method should pay heed to the cautionary statements made by Spokane (1991).

\section{Factor analytic approaches for studying career indecision}

Another approach to studying career indecision inspired by the CDS is the exploratory research on the dimensionality of career indecision using factor analysis. Factor analysis was developed to find the latent dimensions of constructs such as intelligence, personality, interest, and so on. Confirmatory factor analysis has been the prevalent method that has been employed to establish factorial invariance of the factor structure of a given psychological variable (Vandenberg \& Lance, 2000).

The four factors originally reported by Osipow et al. (1976) stimulated further exploratory factor analytic studies. Comparing findings from seven such studies with their own results, Shimizu, 
Vondracek, Schulenberg, \& Hostetler (1988) reported that they were similar to their four factors of the CDS on oblique common factor space even though they were different in some cases regarding the numbers of factors. These four factors identified by Shimizu et al., (diffusion, support, approach-approach, and external barriers) were confirmed to possess factorial invariance by means of structural equation modeling (Schulenberg, Shimizu, Vondracek, \& Hostetler, 1988). Factor analytic studies of the CDS were carried out not only on the original (English language) version but also on translated versions in a number of different languages. A selection of those findings is summarized in Table 1. Interestingly, the multidimensional factors of the CDS extracted from the sixteen items of this scale are quite similar to the classified problems of the diagnostic approach (c.f., Bordin, 1968).

Table 1. Factor analytic studies of the CDS (Osipow, Carney, \& Barak, 1978)

\begin{tabular}{|c|c|c|c|c|}
\hline Scale & Authors & Dimensions & Method & Related Research \\
\hline \multirow[t]{4}{*}{$\begin{array}{l}\text { Career } \\
\text { Decision } \\
\text { Scale (CDS) }\end{array}$} & $\begin{array}{l}\text { Osipow, } \\
\text { Carney, \& } \\
\text { Barak (1978) }\end{array}$ & Two, Three or Four & EFA & $\begin{array}{l}\text { cf. Table } 1 \text { of } \\
\text { Shimizu et al., } \\
\text { (1988) }\end{array}$ \\
\hline & & $\begin{array}{l}\text { Four (Diffusion, Support, } \\
\text { Approach-Approach and } \\
\text { External Barriers) }\end{array}$ & $\begin{array}{l}\text { EFA } \\
\text { and } \\
\text { MGCFA }\end{array}$ & $\begin{array}{l}\text { Shinizu et al, (1988) } \\
\text { and Schulenberg et } \\
\text { al., (1988) }\end{array}$ \\
\hline & & $\begin{array}{l}\text { Four (Lack of Information } \\
\text { about Self and Careers, } \\
\text { Uncertainty about } \\
\text { Appropriateness or Degree of } \\
\text { Fit Between Self and Career, } \\
\text { Multiple Interests, and Specific } \\
\text { Barriers to a Previous Choice) }\end{array}$ & EFA & $\begin{array}{l}\text { Fuqua, Newman, \& } \\
\text { Seaworth (1988) }\end{array}$ \\
\hline & & $\begin{array}{l}\text { Three (Identity Diffusion, } \\
\text { Positive Choice Conflict and } \\
\text { Tentative Decision) }\end{array}$ & MGCFA & Feldt (2013) \\
\hline $\begin{array}{l}\text { Greek } \\
\text { version of } \\
\text { the CDS }\end{array}$ & & $\begin{array}{l}\text { Four (Absence of Structure, } \\
\text { Need for Career Guidance, } \\
\text { Diffusion of Interests, and } \\
\text { Personal Conflicts }\end{array}$ & EFA & $\begin{array}{l}\text { Argyropoulou, } \\
\text { Sidiropoulou- } \\
\text { Dimakakou, \& } \\
\text { Besevegis (2007) } \\
\end{array}$ \\
\hline $\begin{array}{l}\text { Spanish } \\
\text { version of } \\
\text { the CDS }\end{array}$ & & $\begin{array}{l}\text { Four (Lack of Structure, Lack of } \\
\text { Support, Approach-Approach, } \\
\text { and Perceived Barriers) }\end{array}$ & EFA & $\begin{array}{l}\text { Corkin, Arbona, } \\
\text { Coleman, \& Ramirez } \\
(2008)\end{array}$ \\
\hline
\end{tabular}

Note: EFA-Exploratory Factor Analysis; MGCFA-Multi-Group Confirmatory Factor Analysis 
Although the MVS (Holland, et al.,1980) has also been used to diagnose clients having difficulties in career decision-making using three scales (vocational identity, occupational information, and career barriers), the CDS was developed intending to assess career indecision directly using items collected in career counseling practice (Osipow, 1999). The relatively large number of studies conducted to explore the dimensionality of career indecision is very likely a consequence of the controversy surrounding the number of factors of the CDS (Shimizu, Vondracek, \& Schulenberg, 1994). Most of the more recently developed scales of career indecision include some subscales corresponding to dimensions extracted from various factor analytic studies (Table 2).

Kelly and Lee (2002) used joint factor analysis to search for communality among some of the different measures. Specifically, they examined the relationships among the CDS (16 items), CDDQ ( 44 items), and CFI (21 items), and reported the following eight factors: Lack of Information (CDDQ), Need for Information (CFI), Trait Indecision (CFI), Disagreement with Others (CDDQ), Identity Diffusion (CDS), Choice Anxiety (CFI), Positive Choice Conflict (CDS), and Tentative Decision (CDS). Investigating the same measures, Nauta (2012) utilized confirmatory factor analysis with parceled variables and reported five factors: Lack of Information (CDDQ), Need for Information (CFI), Trait Indecision (CFI), Disagreement with Others (CDDQ), and Choice Anxiety (CFI). Among the CDS, CDDQ, and CFI, it appeared that there was no communality on latent variables of career indecision. In conducting a search for the structure of a construct via exploratory factor analysis among such different instruments, it is important that the number of factors is decided appropriately. If the number of factors is too large, the specific factors that are extracted may simply reflect the differences of item statements or response categories among the measures. On the other hand, 


\title{
when the number of factors is too small, such factors might then be considered as representing a kind of general factor.
}

\author{
Table 2. Scales of career indecision and \\ scale construction method
}

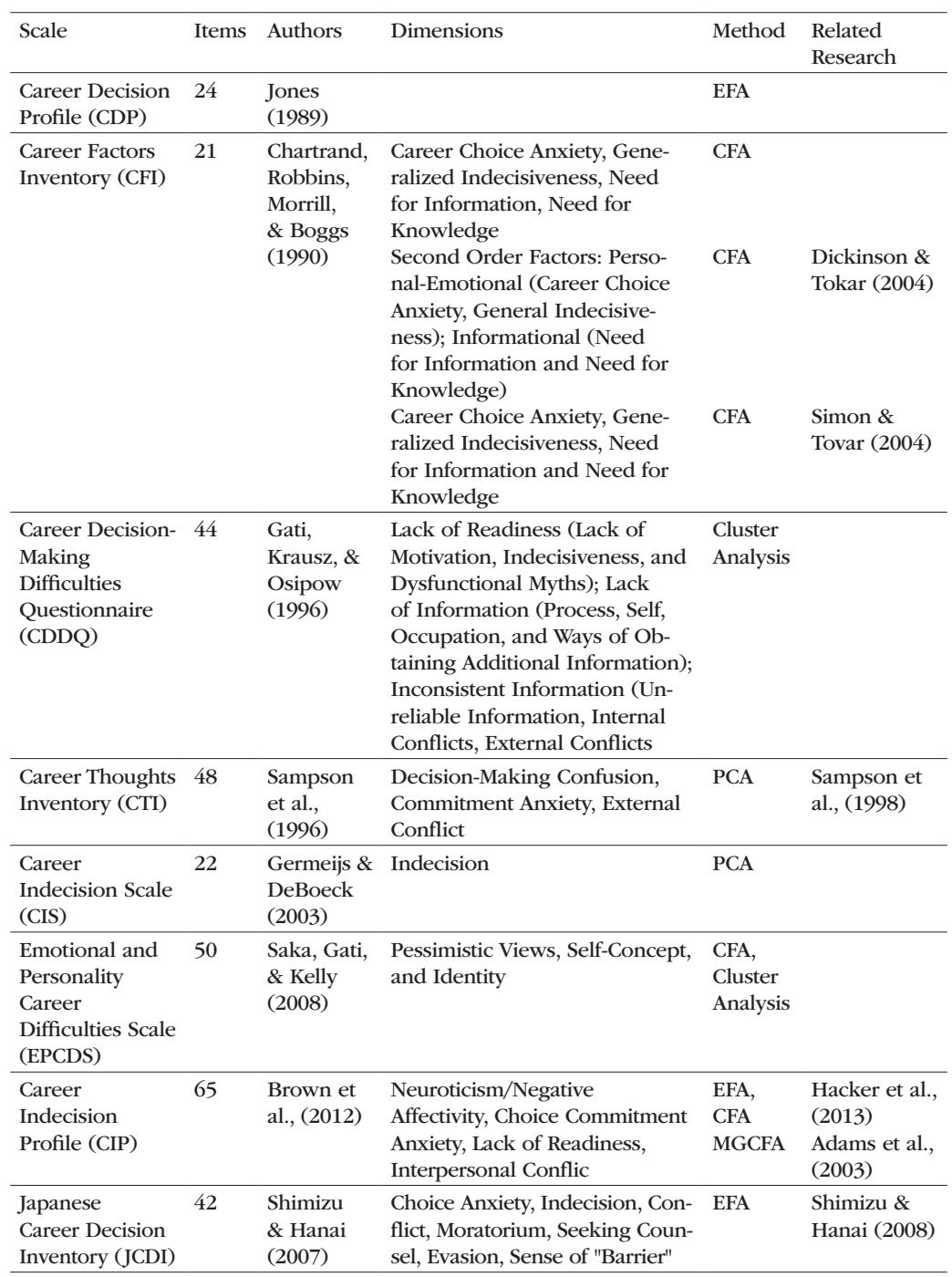

Note: The CDS is not represented on this Table (see Shimizu et al., 1988 and Table 1); Note: EFA-Exploratory Factor Analysis; CFA-Confirmatory Factor Analysis; MGCFA-Multi-Group Confirmatory Factor Analysis 
Appling a meta-analytic approach to 28 correlation matrices published in the research field of career related behavior, Brown and Rector (2008) reported a comprehensive four factor model of career indecision: Neuroticism/Negative Affectivity, Choice/ Commitment Anxiety, Lack of Readiness, and Interpersonal Conflict. Based on these findings, Brown et al. (2012) developed the CPI, consisting of 167 items, to measure their four factors. Subsequently, Hacker, Carr, Abrams, and Brown (2013) developed the short version of the CPI with 65 items and confirmed the four factor structure.

One important difference among the above scales is whether they included a measure of career indecisiveness. After reviewing the scales, it appears that they can be classified into two types: (1) chiefly constructed to measure the career indecision component (e.g., Osipow, 1999; Sampson et al., 1999; Shimizu \& Hanai, 2007), and (2) intentionally constructed to separately assess the career indecisiveness component (e.g., Chartrand et al., 1990; Frost \& Shows, 1993; Gati et al., 1996; Van Matre \& Cooper, 1984; Santos, Ferreira, \& Gonçalves, 2014).

\section{Differentiating between indecision and indecisiveness: Selected validity studies}

As reviewed above, there are already many multidimensional career indecision scales with adequate psychometric properties, which have been constructed appropriately by exploratory or confirmatory factor analysis. However, most of the results in this field were obtained with cross-sectional data, and mostly from traditional correlational analyses.

The study of career indecision has been a long and unique process, at least with regard to the following three observations: 
(1) The measurement of career indecision has been focused on phenomena observed in career counseling situations and not on constructs as investigated in personality psychology; (2) Measurement has been designed to capture change as a consequence of career intervention, as it is desirable that career indecision will change during the counseling process. Nevertheless, a measure that is supposed to produce different results depending on some intervention may not be considered reliable in the context of traditional measurement; (3) Career indecision and career indecisiveness have co-existed. Career indecision is considered to be a state-like concept that may change at different occasions following career intervention, but indecisiveness is considered to be a stable and trait-like phenomenon related to personality (e.g., Osipow, 1999).

A unique contribution to the differentiation of indecision and indecisiveness was made by Crites (1969). Based on Goodstein's (1965) groundbreaking theoretical distinction between indecision and indecisiveness, Crites (1969, p. 601) proposed to use an experimental design with pre-test and post-test of the same measurement to operationally define these constructs. His influential idea has been instrumental in the formulation of longitudinal research on the distinction between career indecision and career indecisiveness with trait and state variables.

Some researchers have treated the two concepts of career indecision and career indecisiveness as independent/orthogonal dimensions (e, g., Van Matre \& Cooper, 1984). Unfortunately, however, there are no statistically concrete differences in psychometric results of repeated measures of scales of these concepts, but rather there are some notable similarities between them. For examples on the CDS, Fuqua, Newman, and Seaworth (1988) discussed the substantial correlations between career indecision and trait anxiety, a relationship that had been predicted by Goodstein's (1965) 
conceptualization of indecision/indecisiveness. Saunders, Peterson, Sampson, and Reardon (2000) reported that the CDS correlated with state anxiety (.27) and with trait anxiety (.29). Mojgan, Kadir, and Soheil (2011) reported also that the CDS correlated with state anxiety (.62) and with trait anxiety (.33). Meanwhile, the stability of the CDS has been reported as being very high (e.g., Creed, Patton, \& Prideaux, 2006; Nauta, 2012). Guay, Ratelle, Senécal, Larose, and Deschênes (2006) reported that the stabilities of the total scores of the CDS were $.54-.38$ on three-year longitudinal data of college students and these scores were correlated with autonomy (-.33 - -.42) and self-efficacy (-.51 - -.59).

Discussing both cognitive and affective aspects of career indecision, Saunders et al. (2000) reported that the CTI also correlated with state anxiety (.36), and with trait anxiety (.42). Di Fabio, Palazzeschi, Asulin-Peretz, and Gati (2013) reported the correlation between the CDDQ and indecisiveness (Frost \& Shows, 1993) was .51 and they discussed subtle differences in the correlations of career indecision and career indecisiveness with emotional stability and extraversion. Although the results obtained with the various scales reviewed above are consistent with generally accepted definitions of career indecision and career indecisiveness, it may still be a bit difficult to operationally discriminate between career indecision and career indecisiveness (Nauta, 2012).

It appears that subtle differences between career indecision and career indecisiveness persist because studies of the two constructs are often based only on data collected for cross-sectional research designs, and also because items of scales to measure these constructs contain both state-like and trait-like aspects. To overcome these limitations, traditional psychometric methodology for scale construction and validity studies should be innovated for the unique concepts of career indecision and career indecisiveness. 


\section{Trait-State distinction approach for career indecision and indecisiveness}

There is an argument that career indecisiveness is different from career indecision in the decision making process (Osipow, 1999). As mentioned above, from this perspective the scales for career indecisiveness should be intentionally constructed independently from any career indecision scale (or subscales). According to another argument, career indecisiveness is regarded as chronic career indecision (Crites, 1969; Fuqua \& Hartman, 1983; Hartman, Fuqua, \& Hartman, 1983). Longitudinal methodologies for research design and data analysis are needed to investigate the substantive features of indecisiveness from this perspective. For example, Vondracek, Hostetler, Schulenberg, and Shimizu (1990) reported that using repeated measures analysis of variance for three waves of data collection at an interval of one year resulted in significantly different change patterns for the multiple subscales of career indecision with regard to measurement properties. They compared the results of the repeated measures analysis of variance for the total score of the CDS and for the four subscales of the CDS, and suggested that the "diffusion" factor might be useful in differentiating career indecisiveness from career indecision.

Adapting the latent state-trait analysis (Steyer, Schmitt, \& Eid, 1999), Jaensch, Hirschi, and Freund (2015) defined three first-order state factors of career indecision and a second-order factor of career indecisiveness for three waves of longitudinal data. Although they also discussed the trait-like nature of career indecisiveness with reference to considerations by Hartman, Fuqua, and Hartman (1983) and Osipow (1999), these state-like factors and trait-like factors were correlated with each other and with self-evaluation and occupational self-efficacy. Jaensch 
et al. (2015) did not decompose the variance of state-like and trait-like, but built the indecisiveness factor on the indecision factors at corresponding measurement occasions.

Nesselroade (1988) discussed such problems in the context of human development as trait-state distinction. He proposed that observed variables can have both, a latent variance of trait and a latent variance of state (also see, Hertzog \& Nesselroade, 1987). Traditionally, it is assumed that items load chiefly on one common factor and that such simple structure is desirable for scale construction. Nesselroade's proposal is that an item as an observed variable loads on two latent factors; one is the trait factor, the other is the state factor. Geiser, Keller, Lochart, Eid, Cole, and Koch (2015) described such a trait-state distinction model. In this model, multistate factors were defined at each occasion of longitudinally repeated observations and singletrait factors were defined as a common latent factor. The developmental trajectory of trait was defined for singletrait through application of latent curve modeling (McArdle \& Nesselroade, 2014). In the context of exploratory factor analysis, it is also noted that bifactor rotation is suitable for containing two kinds of factors (general factor and trait factors) in a single item (Jennrich \& Bentler, 2011).

Thirty years ago, Vondracek, Lerner, and Schulenberg (1986) laid out a forward-looking methodological agenda for career development research. In particular, they emphasized the importance of longitudinal analysis for studying career related behavior. In the present century we have witnessed tremendous methodological and conceptual progress in longitudinal data analysis with structural equation modeling (McArdle \& Nesselroade, 2014). Nevertheless, the accumulation of additional longitudinal design research, using state-of-the-art methods, is required for more definitive studies of the career indecisiveness-indecision distinction. 


\section{References}

Abrams, M. D., Omarsdottir, A. O., Bjornsdottir, M. D., Einarsdottir, S., Martin, C., Carr, A. \& Rector, C. (2013). Measurement invariance of the Career Indecision Profile: United States and Iceland. Journal of Career Assessment, 21, 469-482. doi: 10.1177/1069072712475181

Argyropoulou, E. P., Sidiropoulou-Dimakakou, D., \& Besevegis, E. G. (2007). Generalized self-efficacy, coping, career indecision, and vocational choices of senior high school students in Greece: Implications for career guidance practitioners. Journal of Career Development, 33(4), 316-337. doi: $10.1177 / 0894845307300412$

Baird, L. L. (1968). The Indecision Scale: A reinterpretation. Journal of Counseling Psychology, 15(2), 174-179. doi: 10.1037/h0025474

Baird, L. L. (1969). Prediction of accomplishment in college: A study of achievement. Journal of Counseling Psychology, 16(3), 246 -253. doi: $10.1037 / \mathrm{h} 0027403$.

Bordin, E. S. (1946). Diagnosis in counseling and psychotherapy. Educational and Psychological Measurement, 6, 169-184.

Bordin, E. S. (1968). Psychological counseling (2nd ed.). New York: AppletonCentury-Crofts.

Bordin, E. S., \& Kopplin, D. A. (1973). Motivational conflict and vocational development. Journal of Counseling Psychology, 20, 154-161. doi: 10.1037/ h0034179

Brown, S. D., Hacker, J., Abrams, M., Carr, A., Rector, C., Lamp, K., ... \& Siena, A. (2012). Validation of a four-factor model of career indecision. Journal of Career Assessment,20, 3-21. doi: 10.1177/1069072711417154

Brown, S. D., \& Rector, C. C. (2008). Conceptualizing and diagnosing problems in vocational decision making. In S. D. Brown \& R. W. Lent (Eds.), Handbook of counseling psychology (4th ed., pp.392-407). Hoboken, NJ: Wiley.

Byrne, R. H. (1958). Proposed revisions of the Bordin-Pepinsky diagnostic constructs. Journal of Counseling Psychology, 5, 184-188. doi: 10.1037/ h0039968

Chartrand, J. M., Robbins, S. B., Morrill, W. H., \& Boggs, K. (1990). Development and validation of the Career Factors Inventory. Journal of Counseling Psychology, 37, 491-501. doi: 10.1037/0022-0167.37.4.491.

Corkin, D., Arbona, C., Coleman, N., \& Ramirez, R. (2008). Dimensions of career indecision among Puerto Rican college students. Journal of College Student Development, 49, 1-15. doi: 10.1353/csd.2008.0015

Creed, P., Patton, W., \& Prideaux, L. A. (2006). Causal relationship between career indecision and career decision-making self-efficacy: A longitudinal cross-lagged analysis. Journal of Career Development, 33, 47-65. doi: $10.1177 / 0894845306289535$

Crites, J. O. (1969). Vocational psychology. New York: McGraw-Hill.

Crites, J. O. (1981). Career counseling: Models, methods, and materials. New York: McGraw-Hill. 
Dickinson, J., \& Tokar, D. M. (2004). Structural and discriminant validity of the career factors inventory. Journal of Vocational Behavior, 65, 239-254. doi: $10.1016 /$ j.jvb.2003.07.002

Di Fabio, A., Palazzeschi, L., Asulin-Peretz, L., \& Gati, I. (2013). Career indecision versus indecisiveness: Associations with personality traits and emotional intelligence. Journal of Career Assessment, 21, 42-56. doi: $10.1177 / 1069072712454698$

Feldt, R. C. (2013). Factorial invariance of the Indecision Scale of the Career Decision Scale: A multigroup confirmatory factor analysis. The Career Development Quarterly, 61, 249-255. doi: 10.1002/j.2161-0045.2013.00053.x

Frost, R. O., \& Shows, D. L. (1993). The nature and measurement of compulsive indecisiveness. Behaviour Research and Therapy, 31, 683-692. doi:10.1016/00057967(93)90121-A

Fuqua, D. R., \& Hartman, B. W. (1983). Differential diagnosis and treatment of career indecision. Personnel and Guidance Journal,62, 27-29.

Fuqua, D. R., Newman, J. L., \& Seaworth, T. B. (1988). Relation of state and trait anxiety to different components of career indecision. Journal of Counseling Psychology, 35, 154-158. doi: 10.1037/0022-0167.35.2.154

Gati, I., Krausz, M., \& Osipow, S. H. (1996). A taxonomy of difficulties in career decision making. Journal of Counseling Psychology, 43, 510-526. doi: 10.1037/0022-0167.43.4.510.

Geiser, C., Keller, B. T., Lockhart, G., Eid, M., Cole, D. A., \& Koch, T. (2015). Distinguishing state variability from trait change in longitudinal data: The role of measurement (non) invariance in latent state-trait analyses. Behavior Research Methods, 47, 172-203. doi: 10.3758/s13428-014-0457-z

Germeijs, V., \& De Boeck, P. (2003). Career indecision: Three factors from decision theory. Journal of Vocational Behavior, 62, 11-25. doi:10.1016/ S0001-8791(02)00055-6

Goodstein, L. D. (1965). Behavior theoretical views of counseling. In B. Stefflre (Ed.), Theory of counseling. (pp. 140-192). New York: McGraw-Hill.

Guay, F., Ratelle, C. F., Senécal, C., Larose, S., \& Deschênes, A. (2006). Distinguishing developmental from chronic career indecision: Self-efficacy, autonomy, and social support. Journal of Career Assessment, 14, 235-251. doi: $10.1177 / 1069072705283975$

Hacker, J., Carr, A., Abrams, M., \& Brown, S. D. (2013). Development of the Career Indecision Profile: Factor structure, reliability, and validity. Journal of Career Assessment, 21, 32-41. doi: 10.1177/1069072712453832

Hartman, B. W., Fuqua, D. R., \& Hartman, P. T. (1983). The predictive potential of the Career Decision Scale in identifying chronic career indecision. Vocational Guidance Quarterly, 32, 103-108. doi: 10.1002/j.2164-585X.1983.tb01564.x

Heppner, P. P., \& Petersen, C. H. (1982). The development and implications of a personal problem-solving inventory. Journal of Counseling Psychology, 29, 66-75. doi: 10.1037/0022-0167.29.1.66.

Hertzog, C., \& Nesselroade, J. R. (1987). Beyond autoregressive models: Some implications of the trait-state distinction for the structural modeling of developmental change. Child Development, 58, 93-109. doi: 10.2307/1130294 
Holland, J. L. (1978). Manual for the Vocational Preference Inventory. Consulting Psychologists Press.

Holland, J. L., Daiger, D. C., \& Power, P. G. (1980). My Vocational Situation: Description of an experimental diagnostic form for the selection of vocational assistance. Mountain View, CA: CCP.

Jaensch, V. K., Hirschi, A., \& Freund, P. A. (2015). Persistent career indecision over time: Links with personality, barriers, self-efficacy, and life satisfaction. Journal of Vocational Behavior, 91, 122-133. doi:10.1016/j.jvb.2015.09.010

Jennrich, R. I., \& Bentler, P. M. (2011). Exploratory bi-factor analysis. Psychometrika, 76, 537区549. doi: 10.1007/s11336-011-9218-4

Jones, L. K. (1989). Measuring a three-dimensional construct of career indecision among college students: A revision of the Vocational Decision Scale: The Career Decision Profile. Journal of Counseling Psychology, 36(4), 477-486. doi: 10.1037/0022-0167.36.4.477.

Kelly, K. R., \& Lee, W. C. (2002). Mapping the domain of career decision problems. Journal of Vocational Behavior, 61, 302-326. doi:10.1006/ jvbe.2001.1858

Larson, L. M., Heppner, P. P., Ham, T., \& Dugan, K. (1988). Investigating multiple subtypes of career indecision through cluster analysis. Journal of Counseling Psychology, 35, 439-446. doi: 10.1037/0022-0167.35.4.439

McArdle, J. J., \& Nesselroade, J. R. (2014). Longitudinal data analysis using structural equation models. Washington, DC: American Psychological Association. doi: 10.1037/14440-000

Mojgan, F. N., Kadir, R. A., \& Soheil, S. (2011). The relationship between state and trait anxiety with career indecision of undergraduate students. International Education Studies, 4(3), 31-35. doi: 10.5539/ies.v4n3p31

Nauta, M. M. (2012). Temporal stability, correlates, and longitudinal outcomes of career indecision factors. Journal of Career Development, 39, 540-558. doi: $10.1177 / 0894845311410566$

Nesselroade, J. R. (1988). Some implications of the trait-state distinction for the study of development over the life-span: The case of personality. In P. B. Baltes, D. L. Featherman, \& R. M. Lerner (Eds.), Life-span development and behavior (Vol. 8, pp. 163-189). Hillsdale, NJ: Erlbaum.

Osipow, S. H. (1991). Developing instruments for use in counseling. Journal of Counseling \& Development, 70, 322-326. doi: 10.1002/j.1556-6676.1991. tb01605.x

Osipow, S. H. (1999). Assessing career indecision. Journal of Vocational Behavior, 55, 147-154. doi:10.1006/jvbe.1999.1704

Osipow, S. H., Carney, C. G., \& Barak, A. (1976). A scale of educationalvocational undecidedness: A typological approach. Journal of Vocational Behavior, 9, 233-243. doi: 10.1016/0001-8791(76)90081-6

Pepinsky, H. B. (1948). The selection and use of diagnostic categories in clinical counseling. Applied Psychology Monographs, No. 15.

Robinson, F. P. (1950). Principles and procedures in student counseling. Oxford, UK: Harper. 
Robinson, F. P. (1963). Modern approaches to counseling "diagnosis." Journal of Counseling Psychology, 10, 325-333. doi: 10.1037/h0046712

Rounds, J. B., Jr., \& Tinsley, H.E.A. (1984). Diagnosis and treatment of vocational problems. In S. D. Brown \& R. W. Lent (Eds.), Handbook of counseling psychology (pp. 137-177). New York: John Wiley.

Saka, N., Gati, I., \& Kelly, K. R. (2008). Emotional and personality-related aspects of career-decision-making difficulties. Journal of Career Assessment, 16, 403-424. doi: 10.1177/1069072708318900

Sampson, J. P., Jr., Peterson, G. W., Lenz, J. G., Reardon, R. C., \& Saunders, D. E. (1996). Career Thoughts Inventory. Odessa, FL: Psychological Assessment Resources, Inc.

Sampson, J. P., Jr., Peterson, G. W., Lenz, J. G., Reardon, R. C., \& Saunders, D. E. (1998). The design and use of a measure of dysfunctional career thoughts among adults, college students, and high school students: The Career Thoughts Inventory. Journal of Career Assessment, 6, 115-134. doi: $10.1177 / 106907279800600201$

Santos, P. J., Ferreira, J. A., \& Gonçalves, C. M. (2014). Indecisiveness and career indecision: A test of a theoretical model. Journal of Vocational Behavior, 85, 106-114. doi: 10.1016/j.jvb.2014.05.004

Saunders, D. E., Peterson, G. W., Sampson, J. P., \& Reardon, R. C. (2000). Relation of depression and dysfunctional career thinking to career indecision. Journal of Vocational Behavior, 56(2), 288-298. doi:10.1006/jvbe.1999.1715

Savickas, M. L., \& Jarjoura, D. (1991). The Career Decision Scale as a type indicator. Journal of Counseling Psychology, 38, 85-90. doi: 10.1037/0022-0167.38.1.85

Schulenberg, J. E., Shimizu, K., Vondracek, F. W., \& Hostetler, M. (1988). Factorial invariance of career indecision dimensions across junior high and high school males and females. Journal of Vocational Behavior, 33, 63-81. doi: 10.1016/0001-8791(88)90034-6

Shimizu, K. \& Hanai, Y. (2007). Development of the Career Decision Inventory:(1) Exploratory factor analysis for university students. Bulletin of the Faculty of Sociology, Kansai University, 38(3), 97-118. (In Japanese). http://ci.nii. ac.jp/naid/110006565896

Shimizu, K. \& Hanai, Y. (2008). Stability and change of career decision making related to anxiety: Two-wave longitudinal research at a half-year interval for freshman and sophomore students. Japanese Journal of Career Education, 26(1), 19-30. (In Japanese). http://ci.nii.ac.jp/naid/110007363075

Shimizu, K., Vondracek, F. W., \& Schulenberg, J. (1994). Unidimensionality versus multidimensionality of the career decision scale: A critique of Martin, Sabourin, Laplante, and Coallier. Journal of Career Assessment, 2, 1-14. doi: $10.1177 / 106907279400200101$

Shimizu, K., Vondracek, F. W., Schulenberg, J. E., \& Hostetler, M. (1988). The factor structure of the Career Decision Scale: Similarities across selected studies. Journal of Vocational Behavior, 32, 213-225. doi:10.1016/0001-8791(88)90015-2

Simon, M. A., \& Tovar, E. (2004). Confirmatory factor analysis of the Career Factors Inventory on a community college sample. Journal of Career Assessment, 12, 255-269. doi: 10.1177/1069072703261538 
Slaney, R. B. (1980). Expressed vocational choice and vocational indecision. Journal of Counseling Psychology, 27(2), 122 -129. doi: 10.1037/00220167.27.2.122.

Spokane, A. R. (1991). Career intervention. Englewood Cliffs, N.J.: Prentice Hall.

Steyer, R., Schmitt, M., \& Eid, M. (1999). Latent state-trait theory and research in personality and individual differences. European Journal of Personality, 13, 389-408. doi: 10.1002/(SICI)1099-0984

Vandenberg, R. J., \& Lance, C. E. (2000). A review and synthesis of the measurement invariance literature: Suggestions, practices, and recommendations for organizational research. Organizational Research Methods, 3(1), 4-70. doi: $10.1177 / 109442810031002$

Van Matre, G., \& Cooper, S. (1984). Concurrent evaluation of career indecision and indecisiveness. The Personnel and Guidance Journal, 62, 637-639. doi: 10.1111/j.2164-4918.1984.tb00143.x

Vondracek, F. W., Hostetler, M., Schulenberg, J. E., \& Shimizu, K. (1990). Dimensions of career indecision. Journal of Counseling Psychology, 37, 98-106. doi: 10.1037/0022-0167.37.1.98

Vondracek, F. W., Lerner, R. M., \& Schulenberg, J. E. (1986). Career development: A life-span developmental approach. Hillsdale, NJ: Lawrence Erlbaum.

Wanberg, C. R., \& Muchinsky, P. M. (1992). A typology of career decision status: Validity extension of the vocational decision status model. Journal of Counseling Psychology, 39, 71-80. doi: 10.1037/0022-0167.39.1.71.

Williamson, E. G. (1939). How to counsel students. New York: McGraw-Hill. doi: $10.1037 / 13902-000$. 